\title{
Characterization of siderophore producing arsenic-resistant Staphylococcus sp. strain TA6 isolated from contaminated groundwater of Jorhat, Assam and its possible role in arsenic geocycle
}

Saurav Das ${ }^{1,2}$ and Madhumita Barooah ${ }^{1 *}$

\begin{abstract}
Background: Microorganisms specifically bacteria play a crucial role in arsenic mobilization and its distribution in aquatic systems. Although bacteria are well known for their active participation in the different biogeochemical cycles, the role of these bacteria in regulating the concentration of arsenic in Brahmaputra valley has not been investigated in detail.

Results: In this paper, we report the isolation of an arsenic resistant bacterium TA6 which can efficiently reduce arsenate. The isolate identified as Staphylococcus sp. TA6 based on the molecular and chemotaxonomic identification (FAME) showed resistance to the high concentration of both arsenate and arsenite (As(III) $=30 \mathrm{mM}$; As $(V)=250 \mathrm{mM}$ ), along with cross-tolerance to other heavy metals viz., $\mathrm{Hg}^{2+}, \mathrm{Cd}^{2+}, \mathrm{Co}^{2+}, \mathrm{Ni}^{2+}, \mathrm{Cr}^{2+}$. The bacterium also had a high siderophore activity $(78.7 \pm 0.004 \mu \mathrm{mol})$ that positively correlated with its ability to resist arsenic. The isolate, Staphylococcus sp. TA6 displayed high bio-transformation ability and reduced $2 \mathrm{mM}$ As(V) initially added into $\mathrm{As}$ (III) in a period of $72 \mathrm{~h}$ with $88.2 \%$ efficiency. The characterization of arsenate reductase enzyme with NADPH coupled assay showed the highest activity at $\mathrm{pH} 5.5$ and temperature of $50^{\circ} \mathrm{C}$.

Conclusions: This study demonstrates the role of an isolate, Staphylococcus sp. TA6, in the biotransformation of arsenate to arsenite. The presence of ars operon along with the high activity of the arsenate reductase and siderophore production in this isolate may have played an important role in mobilizing arsenate to arsenite and thus increasing the toxicity of arsenic in the aquatic systems of the Brahmaputra valley.
\end{abstract}

Keywords: Arsenic, Arsenate reductase, Siderophore, Staphylococcus sp., Jorhat, Assam

\section{Background}

Increasing groundwater arsenic contamination is a concern in many developing countries including Bangladesh and India for its negative health impact [1]. In India, the Brahmaputra river basin is reported to harbor high concentration of geogenic arsenic (As) [2]. Out of the 32 districts in Assam, 23 have been reported to be affected by high arsenic concentration [3, 4]. Titabor subdivision of

\footnotetext{
* Correspondence: m17barooah@yahoo.co.in

${ }^{1}$ Department of Agricultural Biotechnology, Assam Agricultural University, Jorhat, Assam 785013, India

Full list of author information is available at the end of the article
}

Jorhat district is considered as one of the most severely arsenic affected areas of Assam with reported As concentration ranging from 194 to $657 \mu \mathrm{g} / \mathrm{l}$, far above the permissible standard of Bureau of Indian Standards (BIS) $(50 \mu \mathrm{g} / \mathrm{l})$ and World Health Organization (WHO) $(10 \mu \mathrm{g} / \mathrm{l})[2,3,5]$ (Additional file 1: Table S1). The very high concentration of arsenic from the Titabor region was also found during the present study (Additional file 1: Table S2). Arsenic is a metalloid widely distributed in the earth's crust and its concentration can exist from traces to up to hundreds of $\mathrm{mg} / \mathrm{kg}$ or $\mathrm{mg} / \mathrm{l}$ in both soil and in water (soil: $01-40 \mathrm{mg} / \mathrm{kg}$; 
water: $10-5000 \mu \mathrm{g} / \mathrm{l}$ ) [6]. In groundwater, the element is predominantly found in two states viz., arsenate $(\mathrm{As}(\mathrm{V}))$ and arsenite $(\mathrm{As}(\mathrm{III}))$. Arsenate is predominant in the oxic environment and gets strongly absorbed by chemicals like ferric-oxyhydroxide, ferrihydrite, apatite, and alumina. The arsenite form is predominant in the anoxic environment and is more mobile and toxic than arsenate [7]. The geochemical cycling of arsenic is composite in nature; involving several physical and chemical factors along with the biological agents. Bacteria play a critical role in mobilization and speciation of arsenical compounds in aquatic systems [8]. Arsenic resistant bacteria have evolved necessary genetic makeup which confers them with the ability to resist high concentration of arsenic as well as other toxic metalloids [9]. Several strains Acidothiobacillus, Aeromonas, Bacillus, Deinococcus, Desulfitobacterium, Exiguobacterium, Flavobacterium, Rhodobacter, Arthrobacter, Acinetobacter, and Pseudomonas are reported to tolerate high concentrations of arsenical elements like arsenate and arsenite [10, 11]. The involvement of the genus Staphylococcus viz., Staphylococcus aureus [12], Staphylococcus succinus [13], and Staphylococcus sp. strain NBRIEAG-8 with high arsenic resistance have been previously reported [14]. However, the arbitrated mechanism of arsenic mobilization by bacteria is still poorly understood and needs further investigation to decipher their role in sediment-bound arsenic mobilization. Bacteria can either reduce, oxidize or can methylate the arsenical compounds in a way of resistance or use them in the cellular respiratory pathway [15]. Arsenate reducing bacteria are able to reduce arsenate $[\mathrm{As}(\mathrm{V})]$ to arsenite $[\mathrm{As}(\mathrm{III})]$ and use the reduced form as an electron acceptor in a respiratory pathway or efflux the same as a mean of resistance mechanisms [16]. Arsenic resistant bacteria are frequently detected with siderophore activity. Siderophore are high-affinity iron chelating compounds produced and secreted by few microorganisms to forage the environmental iron from inorganic phase by formation of soluble $\mathrm{Fe}^{3+}$ complex, which can be taken up by active transport mechanisms [17]. The Fe sequestering ability of bacteria through siderophore production confers them with an added advantages over the non-siderophore producers in arsenic resistance. The previous study has shown that the rate of arsenic uptake and reduction efficiency of a bacteria significantly varies with varied siderophore concentration [18].

In this paper, we report the isolation and characterization of an isolate of bacteria that displayed resistance to high concentration of both arsenate and arsenite. Based on its morphological, molecular and chemotaxonomic characterization the isolate was identified as Staphylococcus sp. TA6. Besides harboring the ars operon, the isolate also produced siderophore and displayed high reduction efficiency (88.2\%), reducing the initial $2 \mathrm{mM}$ arsenate $[\mathrm{As}(\mathrm{V})]$ added to arsenite [As(III)] over a period of $72 \mathrm{~h}$.

\section{Methods \\ Sample collection and isolation}

Contaminated groundwater samples were collected from Tanti-Gaon (GPS: 26.58.101, 94.16.391) (Additional file 2: Figure S1), a village in Titabor subdivision of Jorhat district, Assam, India. The concentration of arsenic in the water samples was measured by atomic absorption spectrophotometer (AAS; PerkinElmer; AAnalyst 400 AA Spectrometer) following the standard protocol as described by Behari and Prakash [19]. The collected samples were enriched in LB broth, subjected to serial dilution and cultured in arsenate amended LB agar plates $(10 \mathrm{mM}$ Arsenate/ $1 \mathrm{mM}$ of Arsenite) and incubated at $30{ }^{\circ} \mathrm{C}$ for $48 \mathrm{~h}$. Individual colonies were picked up based on the morphological identities and sub-cultured to obtain the pure isolates (Additional file 3:Figure S2).

\section{Identification and characterization of new isolate Identification based on 16S rRNA and phylogeny}

Genomic DNA was extracted from approximately $100 \mathrm{mg}$ of the cell as per standard phenol-chloroform method. The $1500 \mathrm{bp}$ region of the 16S rRNA gene was amplified from the extracted genomic DNA using the universal primer 5' TACGGYTACCTTGTTACGACTT 3' (1492R) [20], 5' AGAGTTTGATCMTGGCTCAG 3' (27F) [21]. The amplification was carried out in a reaction with a final volume of $25 \mu \mathrm{l}$ containing $1.5 \mu \mathrm{l}$ of template DNA, $1 \mu \mathrm{l}(20 \mathrm{pM})$ of the forward primer, $1 \mu \mathrm{l}$ (20 pM) of the reverse primer, $2.5 \mu \mathrm{l}(2.5 \mathrm{mM}$ of each) dNTP mix, $2.5 \mu \mathrm{l}$ of $10 \times$ PCR buffer, $1 \mu \mathrm{l}(1 \mathrm{U})$ of Taq DNA polymerase. A negative control (PCR mix without DNA) was included in all PCR experiments. The PCR reaction conditions were set for $94{ }^{\circ} \mathrm{C}$ for $3 \mathrm{~min}$, followed by 30 cycles of denaturation at $94{ }^{\circ} \mathrm{C}$ for $30 \mathrm{~s}$, annealing at $58{ }^{\circ} \mathrm{C}$ for $1 \mathrm{~min}$ and extension at $72{ }^{\circ} \mathrm{C}$ for $2 \mathrm{~min}$, before a final extension at $72{ }^{\circ} \mathrm{C}$ for $7 \mathrm{~min}$. The PCR products were purified using PureLink ${ }^{\text {tm }}$ PCR Purification Kit (Thermo Fischer Scientific, India and sequenced using ABI 3500 8-capillary array sequencer (Applied Biosystems, USA). The forward and reverse sequences obtained were assembled using the Codon-Code Aligner software (version: 5.1). Nucleotide sequence identities were determined using the BLAST tool from the National Center for Biotechnology Information (NCBI) and Similarity index value from EzTaxon Server. The partial sequence data for the 16S rRNA genes have been submitted to GeneBank for further references. Phylogenetic relationship inferred with neighbor-joining (NJ) tree [22]. Sequence divergence among the strains was quantified using Jukes-Cantor 
distance model [23]. A total of 1000 bootstrap replication were calculated for evaluation of the tree topology.

\section{FAME analysis}

The fatty acid methyl ester (FAME) profile was analyzed using Sherlock-Midi system and compared with few reference strains of Staphylococcus genus for taxonomical validation [24].

\section{Minimum inhibitory concentration test}

The minimum inhibitory concentration (MIC) of arsenate $[\mathrm{As}(\mathrm{V})]$ and arsenite [As (III)] was evaluated to determine the resistance capacity of the isolated bacteria. The bacterial isolates were cultured in freshly prepared LB broth at $30{ }^{\circ} \mathrm{C}$ for $48 \mathrm{~h}$ and then $100 \mu \mathrm{l}$ of the freshly cultured bacterial suspension $(0.5$ McFarland Standard $=$ $1.5 \times 10^{8} \mathrm{CFU} / \mathrm{ml}$ ) was inoculated in minimal salt media (MSM) supplemented with different concentration of arsenite $(0.5-30 \mathrm{mM})$ added as sodium meta-arsenite $\left(\mathrm{m}-\mathrm{Na}-\mathrm{AsO}_{2}\right)$ and arsenate $(10-300 \mathrm{mM})$ added as disodium hydrogen arsenate $\left(\mathrm{Na}_{2} \mathrm{HAsO}_{4} \cdot 7 \mathrm{H}_{2} \mathrm{O}\right)$ and incubated for $72 \mathrm{~h}$ at $30{ }^{\circ} \mathrm{C}$ and $142 \mathrm{rpm}$. The microbial growth was recorded with a UV-Visible spectrophotometer at $600 \mathrm{~nm}$.

\section{Growth of the bacterial isolate in the presence and the absence of arsenite/arsenate}

Among all the isolates, TA6 showed the highest MIC and as such, was taken for studying the growth kinetics in presence and absence of arsenite and arsenate. The isolate was cultured in Luria-Bertani broth containing arsenate in a concentration of $1 \mathrm{mM}$ to $30 \mathrm{mM}$ and arsenite from $0.5 \mathrm{mM}$ to $10 \mathrm{mM}$ respectively. The growth of the isolate was monitored through measurement of the optical density (OD) with a spectrophotometer (Thermo-Scientific, India) at $600 \mathrm{~nm}$ (OD600) at a specified interval of time ( $4 \mathrm{~h}, 8 \mathrm{~h}, 12 \mathrm{~h}, 24 \mathrm{~h}, 48 \mathrm{~h}$, and $72 \mathrm{~h}$ ).

\section{Cross tolerance}

The isolate was tested for its cross-tolerance efficiency with other heavy metals like $\mathrm{Hg}^{2+}$ added as $\mathrm{HgCl}_{2}, \mathrm{Cd}^{2+}$ added as $\mathrm{CdCl}_{2}, \mathrm{Co}^{2+}$ added as $\mathrm{CoCl}_{2}, \mathrm{Ni}^{2+}$ added as $\mathrm{NiCl}_{2}$ and $\mathrm{Al}^{3+}$ added as $\mathrm{AlCl}_{3}$ in a concentration ranging from 0.5 to $10 \mathrm{mM}$ in MSM broth culture and absorbance (OD600 $\mathrm{nm}$ ) was recorded after $48 \mathrm{~h}$ to evaluate the bacterial growth.

\section{Biochemical tests and carbon source utilization}

Biochemical tests for starch hydrolysis, catalase, oxidase, casein production, nitrate reduction, urease, malate, citrate, indole, and motility were done according to the standard protocol described by Krieg [25]. Carbon source utilization was tested using BioMerieux $50 \mathrm{CHB} /$ E strips (BioMerieux, USA).

\section{Biotransformation assay}

Qualitative and quantitative biotransformation assay

The ability of the bacteria to reduce As (V) or to oxidize As (III) was evaluated using the silver nitrate $\left(\mathrm{AgNO}_{3}\right)$ method as described by Simeonova et al., [26]. Freshly cultured bacterium grown in minimal salt medium with $5 \mathrm{mM}$ glucose was sub-cultured on two different LB agar plates supplemented with $2 \mathrm{mM}$ of Sodium Meta-Arsenite and Sodium Arsenate respectively and incubated for $48 \mathrm{~h}$ at $30{ }^{\circ} \mathrm{C}$. The streaked plates were then flooded with $0.1 \mathrm{M}$ Silver Nitrate $\left(\mathrm{AgNO}_{3}\right)$ solution. Formation of light yellow color will indicate the precipitation of silver ortho-arsenite $\left(\mathrm{Ag}_{3} \mathrm{AsO}_{3}\right)$ and light brown-red color for precipitation of silver-ortho-arsenate $\left(\mathrm{Ag}_{3} \mathrm{AsO}_{4}\right)$.

Quantitative assay of arsenate reduction was analyzed by culturing the bacteria in arsenic amended LB broth (2 $\mathrm{mM}$ of Arsenate). In a time interval of $6,12,24,48$, $72 \mathrm{~h}$ the bacterial cells were collected by centrifugation and arsenite content of the supernatant was determined by AAS following standard protocols as described by Aggett and Aspell [27].

\section{Arsenate reductase enzyme assay}

The enzyme assay was done using NADPH coupled assay as described by Gladysheva et al., [28]. Cell-free crude extracts of Escherichia sp. SD23 was used as positive control. Effect of $\mathrm{pH}$ and temperature on enzyme activity was also measured using this method.

\section{Siderophore production and quantification Siderophore production}

Production of siderophore was studied using Chrome Azurol S (CAS) agar media as described by Schwyn and Neilands [29]. CAS agar was prepared from four solutions which were sterilized separately before mixing. The solution I: Blue dye was prepared by mixing $10 \mathrm{ml}$ of $1 \mathrm{mM} \mathrm{FeCl}_{3} \cdot 6 \mathrm{H}_{2} \mathrm{O}$ in $10 \mathrm{mM} \mathrm{HCl}$ then with $50 \mathrm{ml}$ of an aqueous solution of $2 \mathrm{mM}$ CAS. The resulting dark purple mixture was added slowly with constant stirring to $40 \mathrm{ml}$ of an aqueous solution of $5 \mathrm{mM}$ Hexa-Decyl Tri-Methyl Ammonium [HDTMA]. The dark blue solution was produced which was autoclaved and then cooled to $50{ }^{\circ} \mathrm{C}$. All reagents in the indicator solution were freshly prepared for each batch of CAS agar. Solution II: CAS agar was prepared by dissolving $30.24 \mathrm{~g}$ of Piperazine-N, $\mathrm{N}^{\prime}$-bis ethane sulfonic acid (PIPES) in $750 \mathrm{ml}$ of a salt solution containing $0.3 \mathrm{~g}$ $\mathrm{KH}_{2} \mathrm{PO}_{4}, 0.5 \mathrm{~g} \mathrm{NaCl}$, and $1.0 \mathrm{~g} \mathrm{NH}_{4} \mathrm{Cl}$. The $\mathrm{pH}$ was adjusted to 6.8 with $50 \% \mathrm{KOH}$, and water was added to bring the volume to $800 \mathrm{ml}$ and autoclaved after adding $15 \mathrm{~g}$ of agar, and then cooled to $50{ }^{\circ} \mathrm{C}$. Solution III: Mix Solution containing the followings: 2 g glucose, $2 \mathrm{~g}$ mannitol, $493 \mathrm{mg} \mathrm{MgSO}_{4}, 7 \mathrm{H}_{2} \mathrm{O}, 1 \mathrm{mg} \mathrm{CaCl}_{2}, 1.17 \mathrm{mg}$ $\mathrm{MnSO}_{4} .7 \mathrm{H}_{2} \mathrm{O}$, $1.4 \mathrm{mg} \mathrm{H}_{3} \mathrm{BO}_{3}, 0.04 \mathrm{mg} \mathrm{CuSO} \mathrm{CH}_{4} .5 \mathrm{H}_{2} \mathrm{O}$, 
$1.2 \mathrm{mg} \mathrm{ZnSO} 4.7 \mathrm{H}_{2} \mathrm{O}$, and $1.0 \mathrm{mg} \mathrm{Na}_{2} \mathrm{MoO}_{4} \cdot 2 \mathrm{H}_{2} \mathrm{O}$, was autoclaved, cooled to $50{ }^{\circ} \mathrm{C}$ then added to the buffer solution along with $30 \mathrm{ml}$ filter-sterilized $10 \%(\mathrm{w} / \mathrm{v})$ casamino acid (Solution IV). The indicator solution was added last, with sufficient stirring to mix the ingredients without forming bubbles. CAS agar plates were inoculated with bacterial isolate and incubated at $30{ }^{\circ} \mathrm{C}$ for 7 days. Colonies showing orange hollow zone following incubation were recognized as siderophore positive [30].

\section{Siderophore quantification}

The method of Alexander et al. [31] was used to measure siderophore production in vitro. The bacterial cells were grown at $30^{\circ} \mathrm{C}$ for $24 \mathrm{~h}$ in $50 \mathrm{ml}$ of Chrome Azurol $\mathrm{S}$ (CAS) medium with $5 \mathrm{mM}$ MES (2-(N-morpholino-ethane-sulfonic acid) $-\mathrm{KOH}$ buffer at $\mathrm{pH}$ 6.8. After the culture growth attains exponential phase at OD-600, the cells were pelleted by centrifugation at $10,000 \mathrm{~g}$ for $10 \mathrm{~min}$ and the supernatant was filtered through $0.25 \mu \mathrm{m}$ filter. Siderophore concentration in the filtrate was measured by mixing $500 \mu \mathrm{l}$ of modified CAS assay solution with $500 \mu \mathrm{l}$ filtrates. The standard solution of deferoxamine-mesylate was used for siderophore quantification. The sterile CAS-MES-KOH solution was used as a reference solution, which did not contain siderophores. A standard curve was prepared by analyzing the absorbance $(630 \mathrm{~nm})$ of the reference solution (A/Aref) as a function of the siderophore concentration.

\section{Resistance to arsenic in comparison to siderophore mutant}

The role of siderophore in arsenic tolerance was determined following the protocol described by Ghosh et al., [18] using one siderophore mutant (non-producer) Pseudomonas putida (Lp10L02M) and one control Acinetobacter guillourie (S02Ar2) with low siderophore production ability $(10.8 \mu \mathrm{mol})$. Arsenic tolerance of the isolate was measured as a percentage of growth rate and $\mathrm{As}(\mathrm{V})$ reduction at 5 and $10 \mathrm{mM}$ of $\mathrm{As}(\mathrm{V})$ modified LB medium incubated at $30{ }^{\circ} \mathrm{C}$ for $24 \mathrm{~h}$ shaking at $142 \mathrm{rpm}$ and compared with the TA6. Growth was measured as OD at $600 \mathrm{~nm}$ on UV-Vis spectrophotometer. All the data were taken in triplicates.

\section{Results}

\section{Groundwater sample}

The contaminated groundwater samples collected from Titabor subdivision had $\mathrm{pH}$ 6.2-7.3 and arsenic concentration of $50-356 \mu \mathrm{g} / \mathrm{l}$.

\section{Isolation of arsenic-resistant bacteria and MIC}

The enriched groundwater sample was inoculated in arsenate amended LB medium and morphologically different bacterial colonies were picked up and tested for minimum inhibitory concentration of arsenate and arsenite. Among the isolates, TA6 showed highest MIC and was able to grow in medium with $250 \mathrm{mM}$ of arsenate and $30 \mathrm{mM}$ of arsenite.

\section{Chemotaxonomic and molecular identification with phylogeny}

The 16S rRNA sequence similarity search identified the isolate as one of the species of the genus Staphylococcus having 98\% pairwise similarity with Staphylococcus saprophyticus subsp. Bovis MM19 and Staphylococcus saprophyticus strain OUCMDZ4189. Fatty acid methyl ester profile showed most of the fatty acids are branched chains like anteiso $\mathrm{C} 15$, anteiso $\mathrm{C} 17$, and iso $\mathrm{C} 15$. Comparative studies with the fatty acid profile of $S$. xylosus, S. cohnii, and S. saprophyticus showed considerable differences of C17:0, iso C17:0, iso C18:0 (Table 1). Therefore, based on both molecular and chemotaxonomic data the bacterium was identified as Staphylococcus sp. and the sequence was submitted under the GeneBank accession: KF134542.1 for further references. Phylogenetic analysis showed significant evolutionary difference among the other member of the Staphylococcus genus but with the similar lineage of origin (Fig. 1). Evolutionary distance computed with Jack Cantor model and 1000 bootstrap value showed TA6 is $67 \%$ homologous on evolutionary lineage with Staphylococcus saprophyticus subsp. Bovis MM19.

\section{Bacterial growth in presence of arsenate and arsenite} Growth curve analysis showed the effect of arsenate and arsenite in the bacterial growth pattern. The isolate TA6 was cultured in fresh LB broth with a concentration of arsenate varying from $1 \mathrm{mM}-30 \mathrm{mM}$ and arsenite from $0.5 \mathrm{mM}-10 \mathrm{mM}$ respectively. Bacterial growth was not much affected in the presence of arsenate as compared with control. However, the presence of arsenite in the medium greatly affected the rate of growth. In the

Table 1 Cellular Fatty acid Profile of isolateTA6 (1) and S. xylosus(2) S. cohnii(3) and S. saprophyticus(4)

\begin{tabular}{lllll}
\hline (\% of total fatty acids) & & & & \\
Straight chain fatty acids & 1 & 2 & 3 & 4 \\
C15:0 & - & - & - & - \\
C16:0 & 1.61 & 3.44 & 3.21 & 3.57 \\
C17:0 & 0.07 & - & - & - \\
Branched chain fatty acids & & & & \\
iso C14:0 & 0.96 & 2.40 & 2.48 & 1.88 \\
iso C15:0 & 14.04 & 23.73 & 15.01 & 21.09 \\
anteiso- C15:0 & 50.58 & 39.24 & 43.28 & 41.55 \\
iso C16:0 & 2.06 & 0.97 & 3.14 & 1.94 \\
iso C17:0 & 6.80 & - & - & - \\
anteiso - C17:0 & 13.13 & 4.48 & 10.18 & 4.66 \\
iso C18:0 & 0.47 & - & 0.62 & - \\
\hline
\end{tabular}




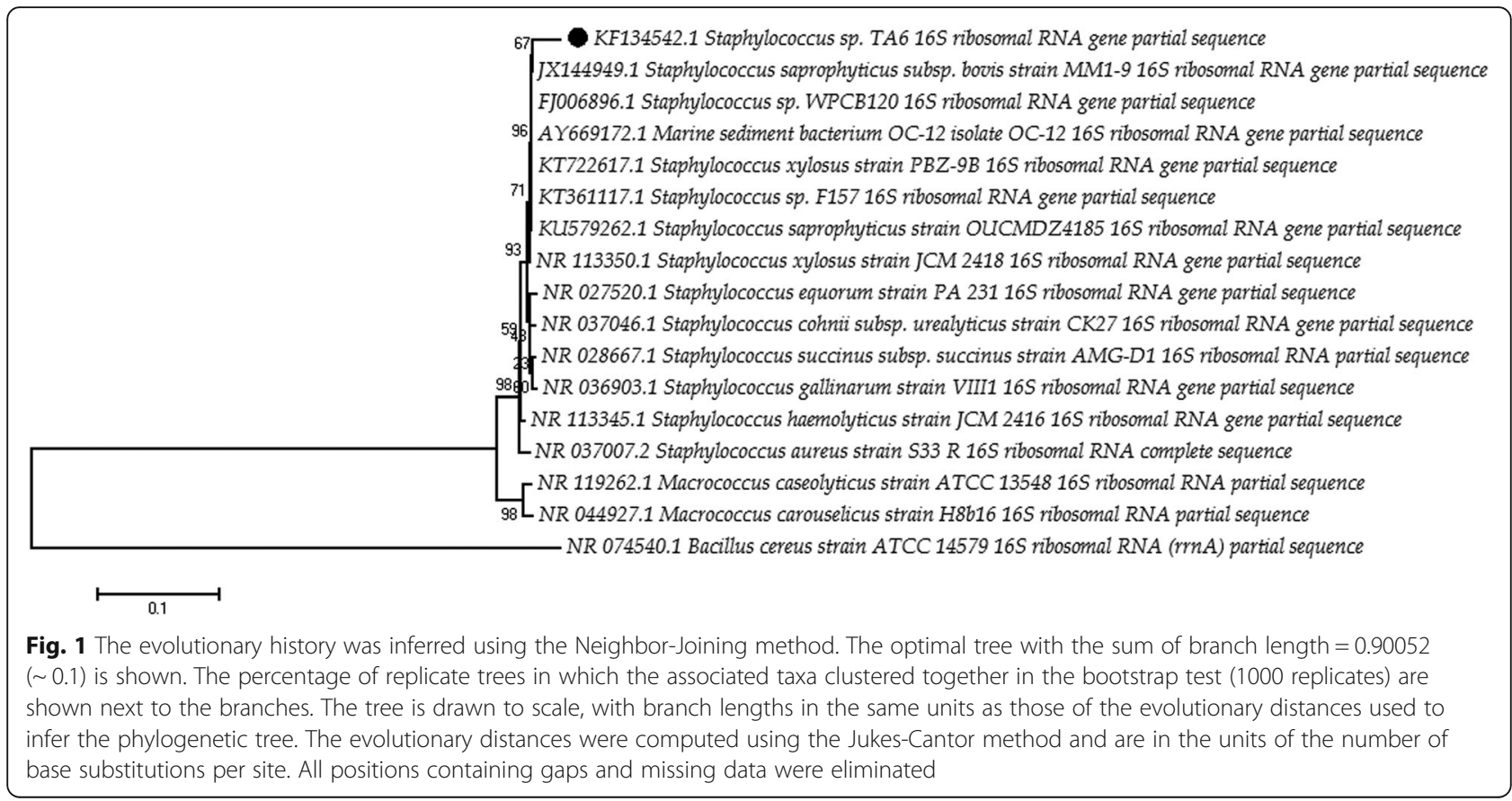

presence of arsenate, TA6 started doubling at the lowest time of $4 \mathrm{~h}$ but in the presence of arsenite, it took approximately $24 \mathrm{~h}$ to start multiplying. At the highest concentration of arsenate $(\sim 30 \mathrm{mM})$ taken for the test and at $72 \mathrm{~h}$ of incubation time, OD was measured as $1.474 \pm 0.067$ and for control OD was recorded $1.962 \pm$ 0.058 at the same time of incubation (Fig. 2b). While, at $72 \mathrm{~h}$ of incubation in the presence of $10 \mathrm{mM}$ of arsenite growth was reduced when compared to the control. For control, OD was recorded as $1.962 \pm 0.058$, whereas in the $10 \mathrm{mM}$ of arsenite, the growth was recorded as OD $0.1036 \pm 0.043$. At lowest concentration of arsenite $0.5 \mathrm{mM}$, the bacterial cell (TA6) approximately took $8 \pm 2$ h of incubation to multiply (Fig. 2a).

\section{Cross tolerance}

Other heavy metal tolerance test also showed the resistive capacity of the isolate to various heavy metals like $\mathrm{Hg}^{2+}, \mathrm{Cd}^{2+}, \mathrm{Co}^{2+}, \mathrm{Ni}^{2+}, \mathrm{Cr}^{2+}$. MIC was found as $0.5 \mathrm{mM}$, $0.8 \mathrm{mM}, 1.0 \mathrm{mM}, 4 \mathrm{mM}$, and $6 \mathrm{mM}$ respectively.

\section{Biochemical test}

The bacterium (TA6) was a gram-positive, non-motile, coccus shaped bacterium. It was able to hydrolyze starch, casein and utilize citrate, reduce catalase and showed high siderophore activity $(78.7 \pm 0.004 \mu \mathrm{mol})$ but tested negative for oxidase, nitrate, urease and indole. Carbohydrate utilization test with $50 \mathrm{CHB} / \mathrm{E}$ showed it could actively utilize Glycerol, D-Glucose, D-Fructose, Maltose, Lactose, Sucrose, Trehalose, Melezitose, Starch, and D-Turanose.

\section{Biotransformation assay}

TA6 was found to be an arsenate reducer. Reduction of arsenate in the petri dish formed a yellow precipitation of silver ortho-arsenite $\left(\mathrm{Ag}_{3} \mathrm{AsO}_{3}\right)$ which indicates the presence of arsenite (Fig. 3a). In the quantitative assay, it was also found that with a gradual increase in time and with the increased bacterial cell count, the concentration of $\mathrm{As}(\mathrm{V})$ gradually decreased with increased concentration of $\mathrm{As}(\mathrm{III})$. In a duration of $72 \mathrm{~h}$, nearly $88.2 \%$ of the initial $2 \mathrm{mM}$ $\mathrm{As}(\mathrm{V})$ is reduced to $\mathrm{As}(\mathrm{III})$ (Fig. 3b).

\section{Arsenate reductase enzyme activity}

Arsenate reductase activity was measured using NADPH coupled oxidation method. A $\mathrm{Km}$ of $0.44 \mathrm{mM}$ arsenate and Vmax of $6395 \mathrm{umol} / \mathrm{min} / \mathrm{ml}$ were measured (Fig. 4). There was no change in activity for $500 \mu \mathrm{M}$ and $1 \mathrm{mM}$ of arsenate. Temperature and $\mathrm{pH}$ are some critical factors for enzyme activity. Temperature-dependent activity assay revealed that $50{ }^{\circ} \mathrm{C}$ was the optimal temperature for highest enzymatic activity and in $\mathrm{pH}$-dependent activity assay, pH 5.5 was measured as optimal for highest enzymatic activity (Fig. 5a). Graphical representation of both the data formed a characteristic bell-shaped curved, where initial increased $\mathrm{pH}$ and temperature raised the activity till it reaches the optimal point of maximum activity and then the activity was found to gradually cease after the respective optimal value of $\mathrm{pH} 5.5$ and temperature $50{ }^{\circ} \mathrm{C}$ (Fig. 5b). 

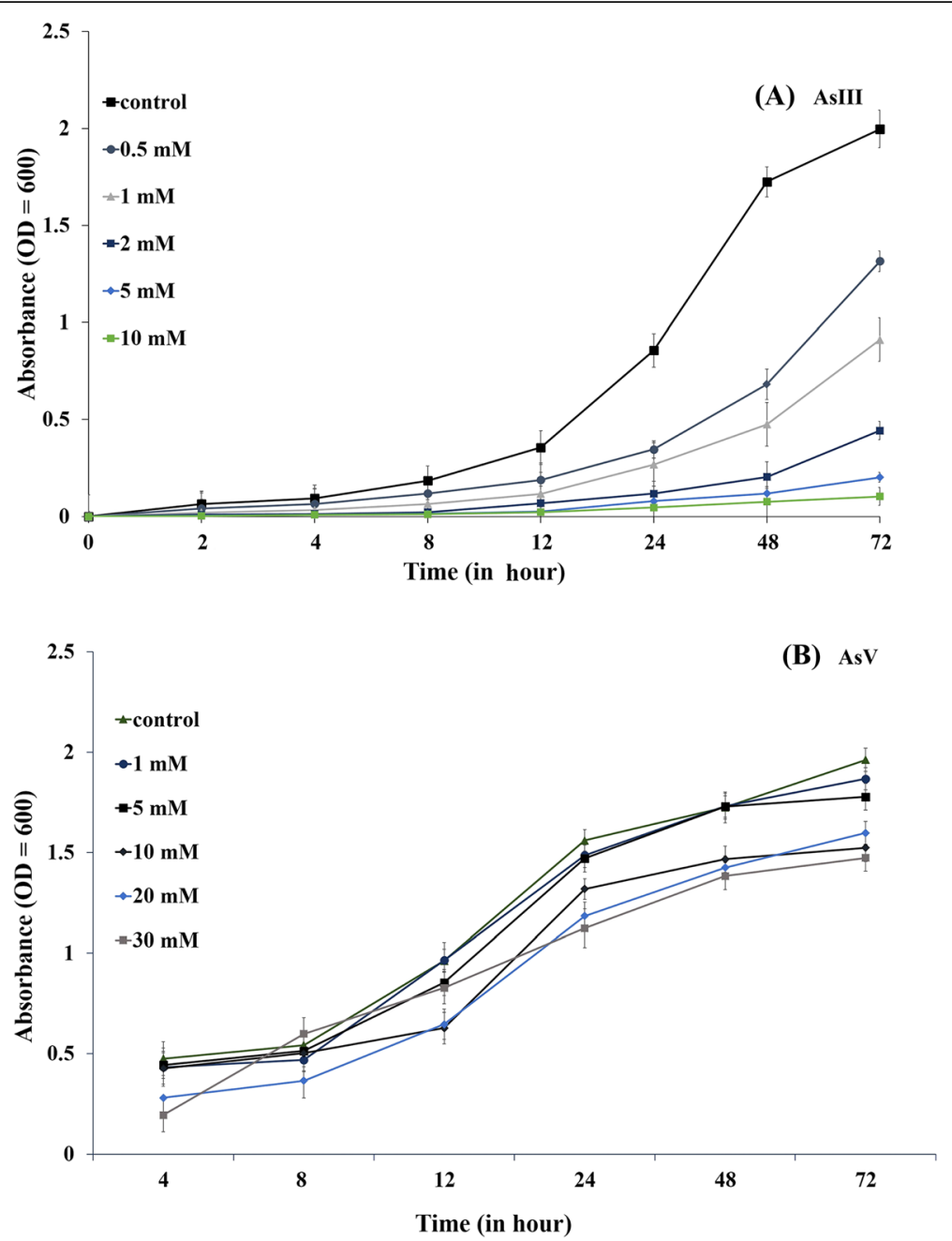

Fig. 2 Effect of arsenic on bacterial growth rate (a) Arsenite (As(III)) (b) Arsenate (As(V))
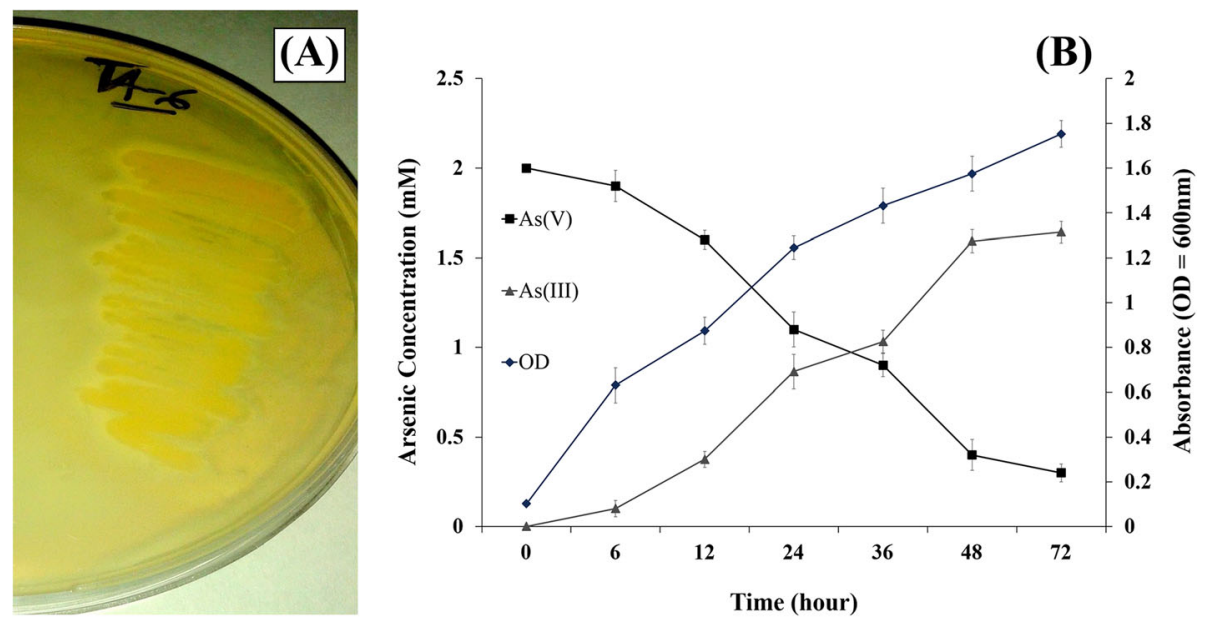

Fig. 3 (a) Bioconversion of arsenate [As (V)] to arsenite [As (III)]. (b) The rate of Biotransformation over an incubation period of $72 \mathrm{~h}$ 


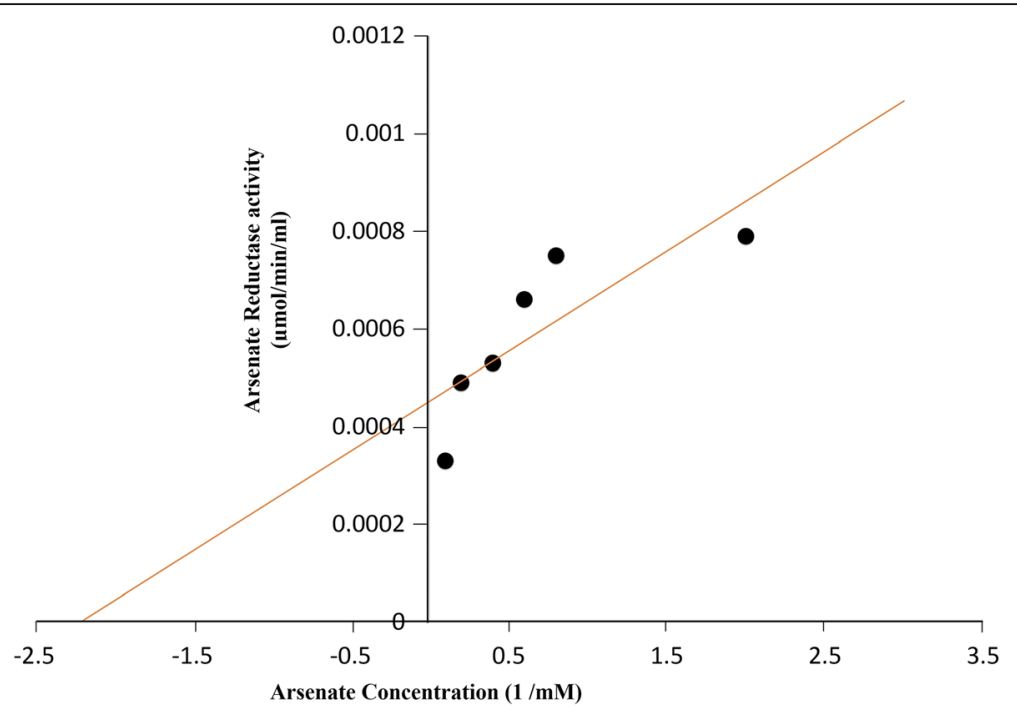

Fig. 4 Kinetic Profile of enzyme activity (Lineweaver Burk Plot)

\section{Siderophore associated arsenate reduction}

Microorganisms are the primary chelator of iron which dissociates $\mathrm{Fe}^{3+}$ ions with their siderophore activity. Siderophore associated arsenic resistance assay revealed that bacteria with high siderophore TA6 $(78.7 \pm 0.004 \mu \mathrm{mol})$ was significantly a strong $\mathrm{As}(\mathrm{V})$ reducer than the mutant strain Lp10L02M (non-producer). The growth of TA6 was also found reflective in comparison to the control and the mutant implying the added resistance ability of the strain to arsenate. In $5 \mathrm{mM}$ and $10 \mathrm{mM}$ arsenate broth, the TA6 showed higher growth as compared to the control strain S02Ar2. However, the mutant strain (Lp10L02M) had slower growth rate as compared to control and showed lesser reduction efficiency (Fig. 6).

\section{Discussion}

Increased arsenic concentration in groundwater has negative impact on the public health due to its carcinogenic nature. The Brahmaputra river basin is considered as one of the severely arsenic contaminated basin in the world [32]. Flood-line areas of the river have been detected with arsenic concentration much above the standard permissible limit set by WHO $(10 \mu \mathrm{g} / \mathrm{l})$ and BIS $(50 \mu \mathrm{g} / \mathrm{l})$ and has become a major health issue for the people residing within these vicinities as they are solely depend on the natural streams and groundwater for potable water. Titabor subdivision of Jorhat district, Assam harbors an alarming concentration of arsenic (194-657 $\mu \mathrm{g} / \mathrm{l})$ [33]. Although, several studies on arsenic poisoning and geogenic distribution of arsenic in this region has been documented [34-36], the role of microbes in the geocycle needs much more attention. Bacteria are known to play important role in the biogeochemical cycle of arsenic and are actively associated with the mobilization of sediment-bound arsenic as indicated from previous studies [37]. Bacteria can interconvert different forms of arsenic through redox reactions and influence the bioavailability, solubility and mobility of arsenical compounds. They employ an array of cellular and metabolic mechanisms including extrusion, entrapment by cellular capsules or by precipitation, oxidation-reduction reaction to resist the toxic concentration of arsenic $[8,38]$. Recent evidences indicates to a major role played by bacteria in mobilizing the arsenic in aquatic system [39-41]. As such, it is imperative to investigate and identify the bacteria controlling the biogeochemical cycling of arsenic to design effective strategies to manage arsenic-contamination in aquatic systems.

We isolated a bacterium TA6 from the groundwater sample containing $356 \mu \mathrm{g} / \mathrm{l}$ of arsenic. The isolate was identified as Staphylococcus sp. based on the 16S rRNA sequence analysis and fatty acid methyl ester (FAME) profile. Both the 16S rRNA and FAME analysis showed significant differences with the reference strains of Staphylococcus. Identity search with the NCBI nr/nt database and EzTaxon server showed an average of 98\% identity with the different species of Staphylococcus genus. Straight chain fatty acids like C16:0, C17:0 and branched chain fatty acids like iso $\mathrm{C} 14: 0$, iso $\mathrm{C} 17: 0$, anteiso $\mathrm{C} 15: 0$ showed differences when compared with the FAME profile of S. xylosus, S. cohnii and S. saprophyticus (Table 1). The bacterium survived in arsenate $(\mathrm{MIC}=250 \mathrm{mM})$ and arsenite ( $\mathrm{MIC}=30 \mathrm{mM}$ ). Resistance to arsenite concentration greater than $10 \mathrm{mM}$ and arsenate greater than $100 \mathrm{mM}$ is considered as significantly high, whereas resistance to $200 \mathrm{mM} \mathrm{As}(\mathrm{V})$ and $30 \mathrm{mM} \mathrm{As}(\mathrm{III})$ is regarded as a hyper-tolerance property [42]. The higher tolerance to inorganic arsenic may be due to the presence of arsenic 

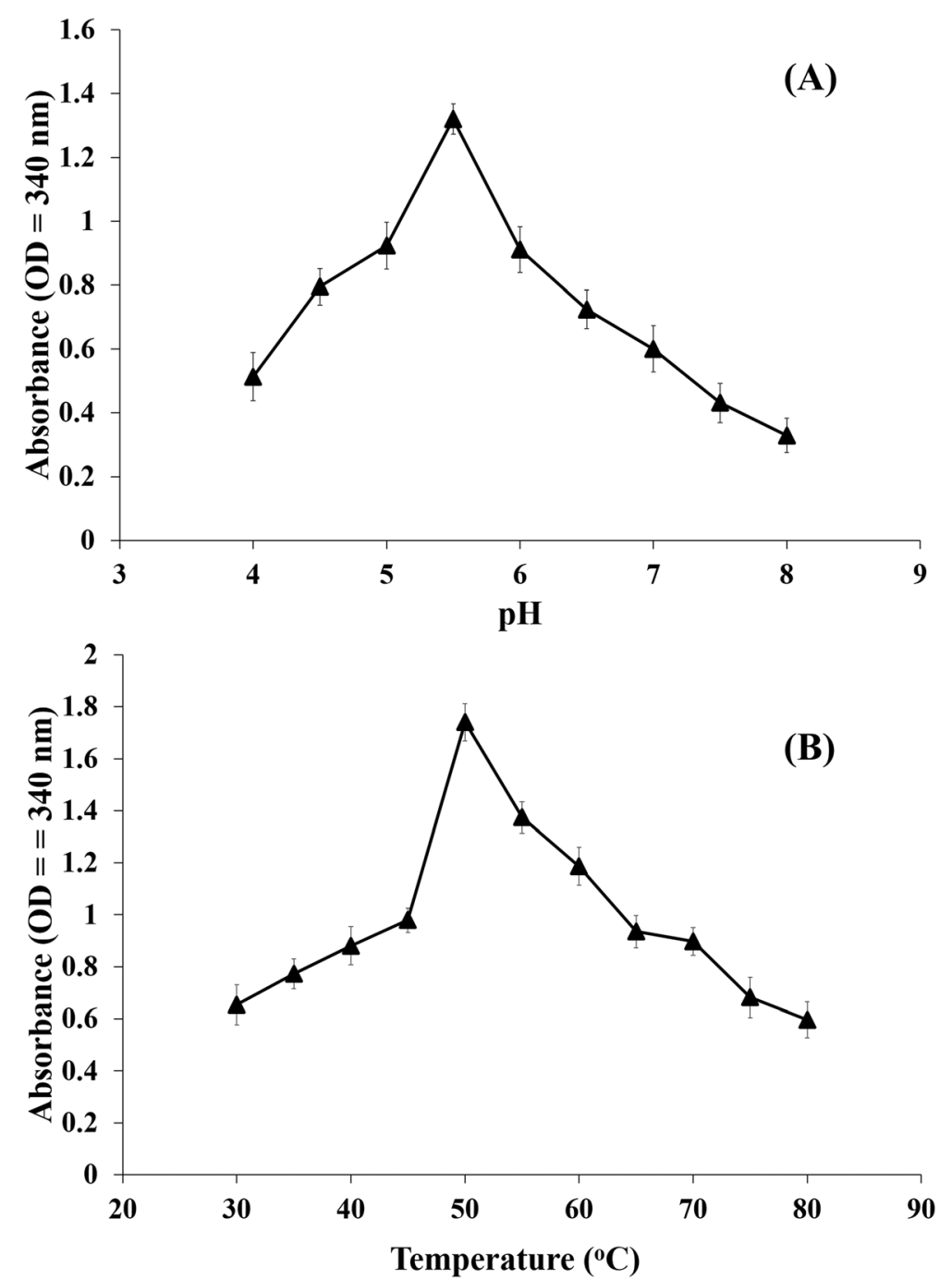

Fig. 5 Arsenate Reductase enzyme activity (a) At different pH (pH 5.5 was found to be optimal for maximum activity) (b) At different Temperature $\left(50{ }^{\circ} \mathrm{C}\right.$ was found as the optimal temperature for maximum activity)

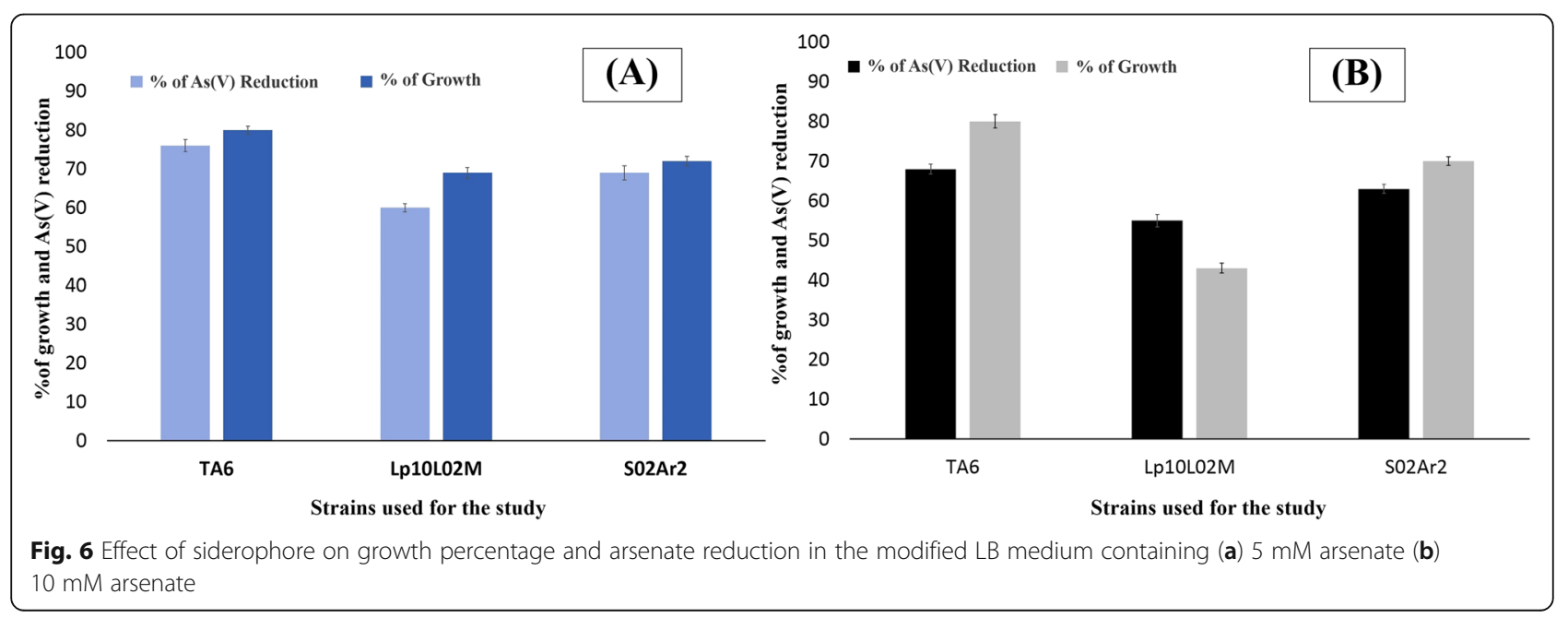


resistance operonic genes (arsR, $\operatorname{ars} \mathrm{B}$, and $\operatorname{ars} \mathrm{C})$ as confirmed by PCR detection method (data not shown). The presence of arsenic resistance genes among the members of Staphylococcus genus is well documented [43-45]. The bacterium also showed resistance to other heavy metals viz., $\mathrm{Hg}^{2+} \mathrm{Cd}^{2+}, \mathrm{Co}^{2+}, \mathrm{Ni}^{2+}, \mathrm{Cr}^{2+,}$ and $\mathrm{MIC}$ ranged from $\geq 0.5-10.0 \mathrm{mM}$.

Bacteria are known for their ability to produce different biogenic chelating agents like siderophore in the iron-limiting environment. Siderophore solubilizes the ferric iron in the iron-starved environment and transports the $\mathrm{Fe}^{3+}$ into the cell [46]. Siderophore enables the bacteria to grow in an environment where iron is the limiting factor [47]. The present isolate under study produced significantly high amount of siderophore $(78.7 \pm 0.004 \mu \mathrm{mol})$. Besides enabling bacteria to grow in an iron-starved environment, siderophore confers an added advantage of increasing resistance to high arsenic concentration as compared to the non-siderophore producers [18]. Screening of comparative resistance efficiency of TA6 $(78.7 \pm 0.004 \mu \mathrm{mol})$ with a control strain Acinetobacter guillourie S02Ar2 $(10.8 \pm 0.003 \mu \mathrm{mol})$ and a mutant strain Pseudomonas putida (Lp10L02M) showed a significant difference. The isolate TA6 was able to resist higher concentration of arsenate in comparison to the mutant and control strain. Siderophore assisted increased resistance to arsenical compounds has been reported earlier [18]. The arsenic reducing efficiency of bacteria is also significantly influenced by varied siderophore concentration. High siderophore concentration confers higher resistance to arsenate as reported earlier [18].

Biotransformation assay revealed the present isolate as efficient arsenate reducer which actively catalyzed the reduction of $\mathrm{As}(\mathrm{V})$ to $\mathrm{As}(\mathrm{III})$ using an enzyme arsenate reductase encoded by ars $\mathrm{C}$ gene of the ars operon. Aerobic arsenate reduction is the most distributed detoxification mechanism present in the bacteria and the ars operon has been detected in more than 50 organisms within the domains of bacteria, yeast, and protist. The first recognized arsenate reductase gene was identified in a gram-positive Staphylococcus plasmid [38]. Since then there have been several reports of this gene in different bacterial species viz. Staphylococcus sp., Thermus thermophiles [48] Bacillus sp., Shewanella sp., [38]. Analysis of NADPH coupled assay revealed the enzyme to be slightly acidic in nature with optimal activity at $\mathrm{pH} 5.5$ and temperature of $50{ }^{\circ} \mathrm{C}$. michaelis Menten kinetic constant, $\mathrm{km}$ was found to be $0.44 \mathrm{mM}$ arsenate and $V_{\max }$ of $6395 \mathrm{umol} / \mathrm{min} / \mathrm{ml}$. A similar kinetics of this enzyme was reported from Chrysiogenes arsenatis with a $\mathrm{Km}$ value of $0.3 \mathrm{mM}$ arsenate and $V \max$ of $7013 \mathrm{umol} / \mathrm{min} / \mathrm{ml}$ [49]. The isolate displayed high reduction efficiency $(88.2 \%)$ reducing the initial $2 \mathrm{mM}$ arsenate $[\mathrm{As}(\mathrm{V})]$ added to arsenite [As(III)] over a period of $72 \mathrm{~h}$. High activity of the enzyme leads to the conversion of arsenate to more mobile arsenite in the shallow aquifers that leads to its accumulation

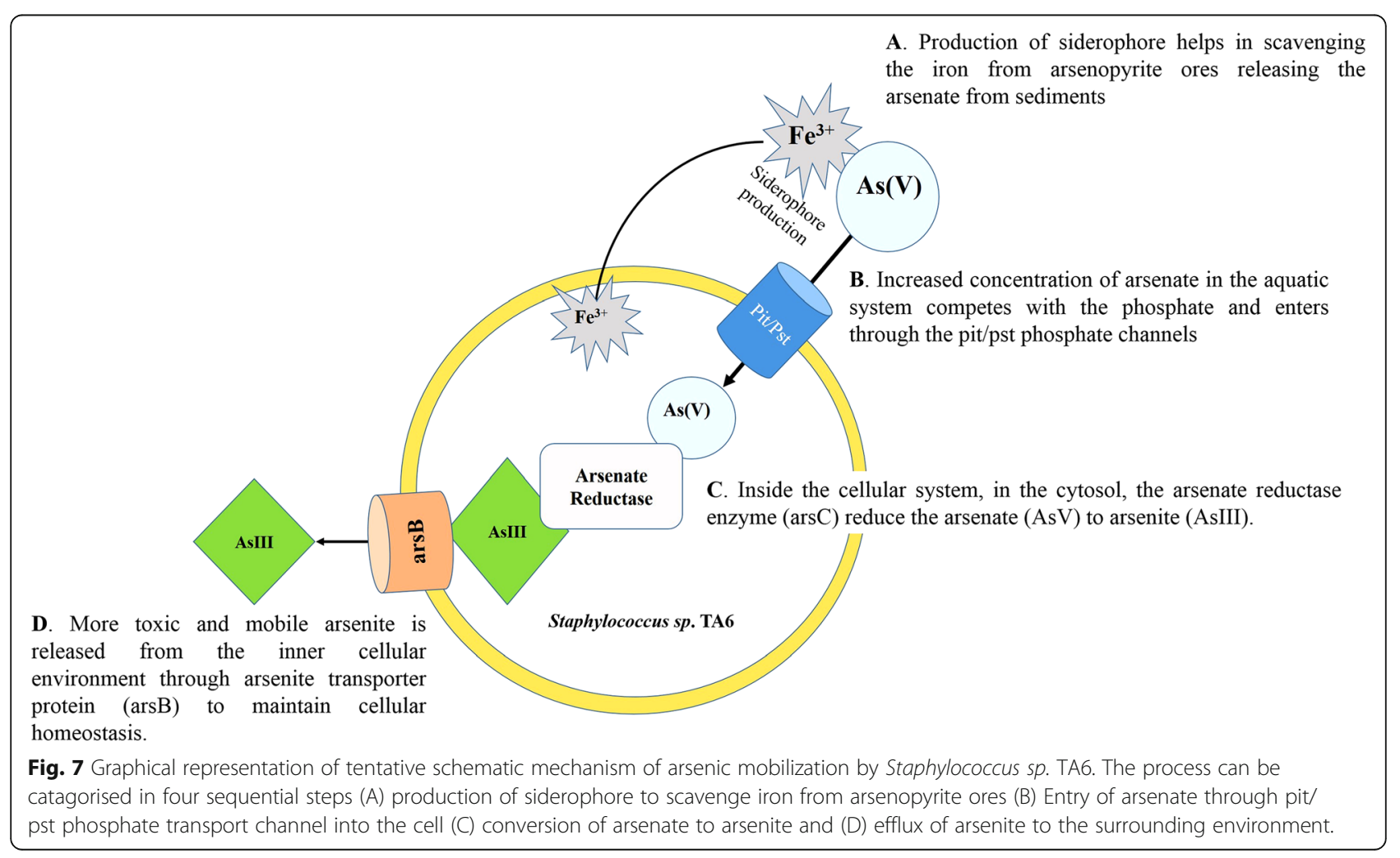


over a time period and could be one of the major reason for the increasing carcinogenic development in the northeastern region. Siderophore produced by the bacteria displaces iron from the iron-arseno compounds (arseno-pyrite) to releases the arsenic and thus aids in the mobilization of the sedimentary arsenate. Increased concentration of arsenate in surrounding milieu competes with the phosphate ion. As the structural homology of the arsenate is similar to phosphate it can enter the cellular system through pit/pst phosphate transporter channel [50]. Cellular arsenate is then converted to arsenite by arsenate reductase enzyme and soon effluxes out of the system through arsenite transporter channel to maintain the cellular homeostasis (Fig. 7) [30]. The increases in the concentration of both arsenite and arsenate in the aquatic system leading to eventually increased arsenic contamination in the Brahmaputra valley.

\section{Conclusion}

Arsenic contaminated groundwater not only affects the human health but also crop health and food supply system when such water is used for irrigation. This leads to the accumulation of As in crops like rice grown extensively in the region and enhances the level of As in the soils rendering them unsuitable for agriculture. Our findings of the role of Staphylococcus sp. TA6 in the mobilization of As sheds further insight into the involvement of bacteria in arsenic distribution in the aquifer systems of the Brahmaputra valley. Further studies can provide information on other potential routes leading to increasing in As concentration in the environment and design effective strategies to make potable water safe.

\section{Additional files}

Additional file 1: Table S1. Arsenic concentration of different districts of Northeastern States as reported by Singh (2004).Table S2 Groundwater profile from Jorhat District (As recorded during this study). (DOCX $19 \mathrm{~kb}$ )

Additional file 2: Figure S1. Map of the study area. (The map was prepared in Microsoft Office PowerPoint 2016). (TIF 3111 kb)

Additional file 3: Figure S2. Pure culture plate of Staphylococcus sp. TA6. (TIF $1857 \mathrm{~kb}$ )

\section{Acknowledgments}

The authors are grateful for the facilities provided by the Department of Agricultural Biotechnology and the DBT-AAU Centre, Assam Agricultural University to carry out the research. The first author gratefully acknowledges UGC for the financial support received in the form of Rajiv Gandhi National Fellowship grant for his Ph.D. studies.

\section{Funding}

University Grand Commission, Govt. of India.

\section{Authors' contributions}

Conceptualization of the project: MB, Investigation: SD, Formal Analysis: SD, Draft Preparation, Review and Edit: SD and MB, Supervision: MB. Both authors read and approved the final manuscript.

Ethics approval and consent to participate

Not Applicable.

\section{Consent for publication}

Not Applicable.

\section{Competing interests}

The authors declare that they have no competing interests.

\section{Publisher's Note}

Springer Nature remains neutral with regard to jurisdictional claims in published maps and institutional affiliations.

\section{Author details}

'Department of Agricultural Biotechnology, Assam Agricultural University, Jorhat, Assam 785013, India. ${ }^{2}$ Present Address: Panhandle Research and Extension Centre, University of Nebraska-Lincoln, Scottsbluff, Nebraska 69361, USA.

Received: 6 January 2018 Accepted: 20 August 2018

Published online: 04 September 2018

\section{References}

1. Dey U, Chatterjee S, Mondal NK. Isolation and characterization of arsenicresistant bacteria and possible application in bioremediation. Biotechnol Reports. 2016:10:1-7.

2. Singh AK. Published in proceedings of national seminar on hydrology with focal theme on water quality held at National Institute of arsenic contamination in groundwater of north eastern India. Hydrology. 2004. http://wilsonweb.physics.harvard.edu/arsenic/references/singh.pdf. Accessed 8 Dec 2017

3. Devi NL, Chandra I, Shihua Q. Recent status of arsenic contamination in groundwater of northeastern India - a review. Rep Opin. 2009;1:22-32.

4. Today N. Water sources in 23 districts of Assam contaminated with arsenic and fluoride » northeast today. 2017. https://www.northeasttoday.in/watersources-in-23-districts-of-assam-contaminated-with-arsenic-and-fluoride/. Accessed 27 Aug 2017.

5. Das S, Bora SS, Prasad JL, Barooah M, Yadav RN, Chetia M. Groundwater arsenic contamination in north eastern states of India. J Environ Res Dev. 2015;9:621-32.

6. Mandal BK, Suzuki KT. Arsenic round the world: a review. Talanta. 2002;58: 201-35.

7. Oremland RS, Stolz JF. Arsenic, microbes and contaminated aquifers. Trends Microbiol. 2005;13:45-9.

8. Mukhopadhyay R, Rosen BP, Phung LT, Silver S. Microbial arsenic: from geocycles to genes and enzymes. FEMS Microbiol Rev. 2002;26:311-25.

9. Abbas SZ, Riaz M, Ramzan N, Zahid MT, Shakoori FR, Rafatullah M. Isolation and characterization of arsenic resistant bacteria from wastewater. Brazilian J Microbiol. 2014;45(4):1309-15.

10. Paul D, Kazy SK, Gupta AK, Pal T, Sar P. Diversity, metabolic properties and arsenic mobilization potential of indigenous bacteria in arsenic contaminated groundwater of West Bengal, India. PLoS One. 2015;10:1-40.

11. Pepi M, Volterrani M, Renzi M, Marvasi M, Gasperini S, Franchi E, Focardi S. Arsenicresistant bacteria isolated from contaminated sediments of the Orbetello Lagoon, Italy, and their characterization. J Appl Microbiol. 2007; 103:2299-2308.

12. Ji G, Silver S. Reduction of arsenate to arsenite by the Ars $\mathrm{C}$ protein of the arsenic resistance operon of Staphylococcus aureus plasmid pl258. Biochemistry. 1992;89:9474-8.

13. Bachate SP, Cavalca L, Andreoni V. Arsenic-resistant bacteria isolated from agricultural soils of Bangladesh and characterization of arsenate-reducing strains. J Appl Microbiol. 2009;107:145-56.

14. Srivastava S, Verma PC, Singh A, Mishra M, Singh N, Sharma N, et al. Isolation and characterization of Staphylococcus sp. strain NBRIEAG-8 from arsenic contaminated site of West Bengal. Appl Microbiol Biotechnol. 2012; 95:1275-91. 
15. Wang G, Huang Y, Li J. Bacteria live on arsenic analysis of microbial arsenic metabolism--a review. Wei Sheng Wu Xue Bao. 2011;51:154-60.

16. Lloyd JR, Oremland RS. Microbial transformations of arsenic in the environment: from soda lakes to aquifers. Elements. 2006;2:85-90.

17. Kraemer SM. Iron oxide dissolution and solubility in the presence of siderophores. Aquat Sci Res Across Boundaries. 2004;66:3-18.

18. Ghosh P, Rathinasabapathi B, Teplitski M, Ma LQ. Bacterial ability in AsIII oxidation and AsV reduction: relation to arsenic tolerance, $\mathrm{P}$ uptake, and siderophore production. Chemosphere. 2015;138:995-1000.

19. Behari JR, Prakash R. Determination of total arsenic content in water by atomic absorption spectroscopy (AAS) using vapour generation assembly (VGA). Chemosphere. 2006;63:17-21.

20. Turner S, Pryer KM, Miao VPW, Palmer JD. Investigating deep phylogenetic relationships among cyanobacteria and plastids by small subunit rRNA sequence analysis. J Eukaryot Microbiol. 1999;46:327-38.

21. Hogg JC, Lehane MJ. Identification of bacterial species associated with the sheep scab mite (Psoroptes ovis) by using amplified genes coding for $16 \mathrm{~S}$ rRNA. Appl Environ Microbiol. 1999;65:4227-9.

22. Saitou N, Nei M. The neighbor-joining method: a new method for reconstructing phylogenetic trees. Mol Biol Evol. 1987;4:406-25.

23. Erickson K. The jukes-cantor model of molecular evolution. Primus. 2010;20: 438-45.

24. Buyer JS. Rapid sample processing and fast gas chromatography for identification of bacteria by fatty acid analysis. J Microbiol Methods. 2002;51: 209-15.

25. Krieg NR, Krieg RN. Spirillum. Bergey's Man Syst Archaea Bact. Chichester: John Wiley \& Sons, Ltd; 2015. p. 1-14

26. Simeonova DD, Lièvremont D, Lagarde F, Muller DA, Groudeva VI, Lett MC, et al. Microplate screening assay for the detection of arsenite-oxidizing and arsenate-reducing bacteria. FEMS Microbiol Lett. 2004;237:249-53.

27. Aggett J, Aspell AC. The determination of arsenic(III) and total arsenic by atomic-absorption spectroscopy. Analyst. 1976;101:341.

28. Gladysheva TB, Oden KL, Rosen BP. Properties of the arsenate reductase of plasmid R773. Biochemistry. 1994;33:7288-93.

29. Schwyn B, Neilands JB. Universal chemical assay for the detection and determination of siderophores. Anal Biochem. 1987;160:47-56.

30. Sarkar A, Kazy SK, Sar P. Characterization of arsenic resistant bacteria from arsenic rich groundwater of West Bengal, India. Ecotoxicology. 2013;22:363-76.

31. Alexander DB, Zuberer DA. Use of chrome azurol S reagents to evaluate siderophore production by rhizosphere bacteria. Biol Fertil Soils. 1991;12:39-45.

32. Chetia M, Chatterjee S, Banerjee S, Nath MJ, Singh L, Srivastava RB, et al. Groundwater arsenic contamination in Brahmaputra river basin: a water quality assessment in Golaghat (Assam), India. Environ Monit Assess. 2011; 173:371-85.

33. Das S, Bora S, Lahan J, Barooah M, Yadav R, Chetia M. Groundwater arsenic contamination in north eastern states of India. J Environ Res Dev J Environ Res Dev. 2014;9:621-632

34. Mahanta C, Choudhury R, Basu S, Hemani R, Dutta A, Barua PP, et al. Preliminary assessment of arsenic distribution in Brahmaputra River basin of India based on examination of 56,180 public groundwater wells. Safe sustain use arsenic-contaminated aquifers Gangetic plain. Cham: Springer International Publishing; 2015. p. 57-64.

35. Chakraborty M, Mukherjee A, Ahmed KM. A review of groundwater arsenic in the Bengal Basin, Bangladesh and India: from source to sink. Curr Pollut Rep. 2015;1(4):220-47.

36. Mukherjee A, Sengupta MK, Hossain MA, Ahamed S, Das B, Nayak B, et al. Arsenic contamination in groundwater: a global perspective with emphasis on the Asian scenario. J Health Popul Nutr. 2006;24:142-63.

37. Islam F, Gault G, Bootham C, Polya D, Charnock J, CHatterjee D, et al. Role of metal-reducing bacteria in arsenic release from Bengal delta sediments. Nature. 2004:430:68.

38. Silver S, Phung LT. Genes and enzymes involved in bacterial oxidation and reduction of inorganic arsenic. Appl Environ Microbiol. 2005;71:599-608.

39. Turpeinen R, Pantsar-Kallio M, Häggblom M, Kairesalo T. Influence of microbes on the mobilization, toxicity and biomethylation of arsenic in soil. Sci Total Environ. 1999;236:173-80.

40. Xie Z, Wang Y, Duan M, Xie X, Su C. Arsenic release by indigenous bacteria Bacillus cereus from aquifer sediments at Datong Basin, northern China. Front Earth Sci. 2011;5:37-44
41. Park JM, Lee JS, Lee J-U, Chon HT, Jung MC. Microbial effects on geochemical behavior of arsenic in as-contaminated sediments. Geochemical Explor. 2006;88:134-8.

42. Jackson C, Jackson E, Dugas S, Gamble K, William S. Microbial transformations of arsenite and arsenate in natural environments. Recent Res Dev Microbiol. 2003;7:103-18.

43. Silver S, Budd K, Leahy KM, Shaw WW, Hammond D, Novick RP, et al. Inducible plasmid-determined resistance to arsenate, arsenite, and antimony (III) in escherichia coli and Staphylococcus aureus. J Bacteriol. 1981;146:983-96.

44. Ji G, Silver S. Regulation and expression of the arsenic resistance operon from Staphylococcus aureus plasmid pl258. J Bacteriol. 1992;174:3684-94.

45. Srivastava S, Verma PC, Chaudhry V, Singh N, Abhilash PC, Kumar KV, et al. Influence of inoculation of arsenic-resistant Staphylococcus arlettae on growth and arsenic uptake in Brassica juncea (L.) Czern. Var. R-46. J Hazard Mater. 2013:262:1039-47.

46. Hammer ND, Skaar EP. Molecular mechanisms of Staphylococcus aureus Iron acquisition. Annu Rev Microbiol. 2011;65:129-47.

47. Basavraj N, Deepak V. Medical applications of siderophores. Eur J Gen Med. 2011;8:229-35.

48. Del Giudice I, Limauro D, Pedone E, Bartolucci S, Fiorentino G. A novel arsenate reductase from the bacterium Thermus thermophilus HB27: its role in arsenic detoxification. Biochim Biophys Acta - Proteins Proteomics. 2013; 1834:2071-9.

49. Krafft T, Macy J. Purification and characterization of the respiratory arsenate reductase of Chrysiogenes arsenatis. FEBS J. 1998;255:647-53.

50. Elias M, Wellner A, Goldin-Azulay K, Chabriere E, Vorholt JA, Erb TJ, et al. The molecular basis of phosphate discrimination in arsenate-rich environments. Nature. 2012:491:134-7.

Ready to submit your research? Choose BMC and benefit from:

- fast, convenient online submission

- thorough peer review by experienced researchers in your field

- rapid publication on acceptance

- support for research data, including large and complex data types

- gold Open Access which fosters wider collaboration and increased citations

- maximum visibility for your research: over $100 \mathrm{M}$ website views per year

At $\mathrm{BMC}$, research is always in progress.

Learn more biomedcentral.com/submissions 